\title{
PHYTOCHEMICAL CONSTITUENTS OF SELECTED PLANTS FROM APIACEAE FAMILY AND THEIR BIOLOGICAL EFFECTS IN POULTRY
}

\author{
Milica G. Aćimović ${ }^{* 1}$, Ljiljana M. Kostadinović ${ }^{1}$, Nikola M. Puvača², Sanja J. Popović ${ }^{1}$, Miroslav I. \\ Urošević $^{3}$ \\ ${ }^{1}$ University of Novi Sad, Institute for Food Technology, 21000 Novi Sad, \\ Bulevar cara Lazara 1, Serbia \\ ${ }^{2}$ University of Novi Sad, Faculty of Agriculture, 21000 Novi Sad, \\ Trg Dositeja Obradovića 8, Serbia \\ ${ }^{3}$ Scientific Institute for Reproduction and Artificial Insemination of Domestic Animals "Temerin", 21235 \\ Temerin, Ind. zona bb., Serbia
}

*Corresponding author:
Phone: +381214853752
Fax: +38121450725
E-mail address: acimovicbabicmilica@gmail.com

\begin{abstract}
The dried ripe fruits of the plants from Apiaceae family are used in folk medicine for treating digestive disorders. They can be used in veterinary and animal production, especially poultry, as immunostimulants and as natural antibiotics. Plants from Apiaceae family improve performance parameters of poultry and can be used for prevention of diseases. This article is a review of present literature data on the usage of caraway, anise, coriander and fennel in broiler chickens and Japanese quail nutrition and their mode of action and effects on production performance, blood parameters, cholesterol and fatty acids profile.
\end{abstract}

Key words: caraway, anise, coriander, fennel, productive performance, natural antibiotics

\section{INTRODUCTION}

The dried ripe fruits of the plants from Apiaceae family are used in folk medicine especially in the treatment of digestive disorders. They are also used as spices, flavoring agents and as dietary supplements in nutrition (Acimovic et al., 2015a). Apart from this, these plants have real application in foods. The essential oils presented in Apiaceae plants gives them the flavor and stimulate the digestive enzymes and by doing this improve nutrient digestibility.

The benefits that accrue as a consequence are better performance and meat quality of broiler chicks (Lee et al., 2004; Giannenas et al., 2013). The use of antibiotic growth promoters in livestock production within the European Union has been prohibited since 2006. As a result, new commercial additives derived from plants, including aromatic plant extracts and their purified constituents have been examined as a part of alternative feed strategies for the future (Brenes and Roura, 2010). Such products have several advantages over commonly used commercial antibiotics since they are residue-free and they are also, generally recognized as safe and commonly used items in food industry.

The use of natural "antibiotics" such as phytobiotics and medicinal plants in animal nutrition as antimicrobial growth promoters 
is undoubtedly beneficial for the improvement of zootechnical performance parameters and for prevention of certain diseases (Windisch et al., 2009; Puvaca et al., 2013; Kostadinovic et al., 2015a). Antibacterial action improves this performance in different ways, by reducing the incidence and severity of subclinical infections, reducing the microbial use of nutriaents, improving absorption of nutrients caused by the thinning of the intestinal wall, and by reducing the amount of growth-depressing metabolites produced by Gram-positive (Huyghebaert et al., 2011).

Herbs, spices and essential oils are summarized under the terms botanicals, phytobiotics or phytogenics. Phytobiotics are well known for their pharmacological effects and are thus widely used in human traditional and alternative medicine (Kostadinovic et al., 2015b; Puvaca et al., 2015; Akbarian et al., 2015; Panda et al., 2006). Furthermore, phytobiotics play an important role as flavors and food preservatives in human nutrition. The activity of phytobiotics is caused by primary and secondary ingredients. A huge number of in vitro and in vivo studies have confirmed a wide range of activities of phytobiotics in animal nutrition. These include the stimulation of feed intake, antimicrobial, coccidiostatic, anthelmintic and immunostimulating activities (Grashorn, 2010). Many scientific experiments have been conducted to determine whether the use of aromatic plants and the addition of essential oils to the food improve the health and the growth of poultry.

\section{Caraway (Carum carvi L.)}

Caraway fruits usually contain around $4 \%$ of essential oil, with more than $20 \mathrm{com}$ pounds, out of which only two, carvone and limonene, constitute more than 90\% of the total oil composition (Acimovic et al., 2014a). Caraway has great importance in traditional, as well as in modern medicine (Deepak, 2013; El-Soud et al., 2014). It is often used in veterinary medicine, as in human medicine, for the stimulation of appetite and feed intake, improvement of endogenous digestive enzyme secretion, activation of immune response and antibacterial, antiviral, antioxidant and antihel- minthic activities (Hassan and Abdel-Raheem, 2013).

The effects that the use of different levels of caraway powder $(1.0 \%, 1.5 \%$ and $2.0 \%$ in basal diet) had on the performance of broiler chickens was determined and data showed that the use of caraway caused the decrease in feed conversation ratio with increasing body weight. Even though the use of caraway reduced abdominal fat, statistically significant effects in terms were not observed. Drumstick percentage was increased in broilers fed with caraway. Breast meat percentage was higher than others by incorporating caraway by $2.0 \%$, but there were no significant effects on breast meat percentage between treatments. The amount of triglyceride was lower when chicks were fed $2.0 \%$ of caraway seed, while blood calcium increased. Antibodies titers against New Castle Vaccine were significantly higher when broilers were fed with a higher content of caraway (Khajeali et al., 2012).

In another study, seven-day-old Japanese quail were used in order to determine the effect of dietary supplementation when applying different levels of caraway seed powder, same as in the previous study $(1.0 \%, 1.5 \%$ and $2.0 \%)$. The results showed that using caraway in their diet had a significant effect on performance, carcass traits and blood biochemical parameters. The highest amount of average daily gain and the best result for feed conversion ratio, as well as the highest percentage of breast was observed in the group with $2.0 \%$ supplementation of caraway powder. The highest level of daily feed intake was $1.5 \%$. The results also show that the serum total cholesterol and triglycerides concentration were significantly reduced in groups with 1.5 and $2.0 \%$ supplementation of caraway when compared to the control group (Jafari, 2011).

\section{Anise (Pimpinella anisum L.)}

Anise fruits contain around $4 \%$ of essential oil with trans-anethole as the dominant compound, which comprises up to $90 \%$ of the oil (Acimovic et al., 2014b; Acimovic et al., 2015c). Anise has great pharmacological importance, and due to many health benefits it can be used in food as a 
nutraceuticals (Acimovic and Dojcinovic, 2014; Rattan et al., 2014). In the trial with broiler chickens, anise seed was supplemented to the basal diet in different doses: $0.25,0.5,0.75,1.0,1.25$ and 1.5 $\mathrm{g} / \mathrm{kg}$. The obtained data indicated that anise supplementation at $0.5 \mathrm{~g} / \mathrm{kg}$ give the best results, i.e. had stimulatory immune effect, provide hepatoprotective effect and improve the economical efficiency of production. However, highest inclusion level of anise to the basal diet $(1.5 \mathrm{~g} / \mathrm{kg})$ had negative effect on spleen, bursa and thymus gland weight percent (Soltan et al., 2008).

In another study the effect of the inclusion of three levels of anise seed as an antibiotic and alternative growth promoter in basal diet in addition of 1.0, 5.0 and 10.0 $\mathrm{g} / \mathrm{kg}$ was evaluated. According to the obtained results, it can be concluded that feed conversion ratio is most efficient in diet supplemented with $1.0 \mathrm{~g} / \mathrm{kg}$, while antibody titer against avian influenza virus increased in the group treated with 10.0 $\mathrm{g} / \mathrm{kg}$. These results suggested that the dietary inclusion of $10.0 \mathrm{~g} / \mathrm{kg}$ of anise seed can be applied as an alternative to in-feed antibiotics for broiler diets (Yazdi et al., 2014).

Apart from seeds, anise essential oil can also be used in diets. Experiments were done with different levels of anise oil (100, 200 and $400 \mathrm{mg} / \mathrm{kg}$ ) added to a standard diet, in order to determine its effect on feed intake, daily live weight gain and feed conversion ratio compared with control and antibiotic group. The feed intake was similar in all groups, while the highest daily live weight gain was observed with the 400 $\mathrm{mg} / \mathrm{kg}$ anise oil group, followed by antibiotic group (Ciftci et al., 2005).

The analysis of the effect of mixed oil herb extract containing Artemisia annua, Hyssopus officinalis and Pimpinella anisum on Eimeria spp. oocyst, concluded that this herb oil mixture achieved good results against this pathogen (Titilincu et al., 2008). In another study, the anticoccidial effect of Pimpinella anisum essential oil in concentration of $7.5 \%$ in diets on Eimeria tenella infection was investigated. According to the results, anise did not have a good anticoccidial effect (reduction in fecal oocyst output of $58.83 \%$ was noticed and the lesional score was 1.2), but improved the weight gain and feed conversion ratio (Dragan et al., 2010). The residue cake after anise essential oil extraction was included as feed additive in diets of broilers. The broilers received $0.1,0.5$ and $1.0 \%$ anise seed cake for a period of six weeks. According to the results it can be concluded that $0.1 \%$ group had the best feed conversation ratio and a significantly heavier bursa. Therefore, the anise seed cake as feed additive can be used for growth performance and immunity that is suitable to replace antibiotic feed additives (Yazdi et al., 2011).

\section{Coriander (Coriandrum sativum L.)}

Coriander seeds contain around $1 \%$ essential oil, with linalool as the main compound (Acimovic et al., 2011). In order to determine the effect of different levels of coriander seed supplementation in diets on performance and blood parameters, broiler chicken were fed with basal diets or the basal diet supplemented with $0.1,0.2$ and $0.3 \%$ of coriander seed. From the obtained results it can be concluded that birds fed with $0.3 \%$ coriander seed diet exhibited the highest body weight gain, feed conversation ratio and carcass yield and decreased feed intake and abdominal fat pad. There were differences in packed cell volume percentage, red blood cell count and hemoglobin concentration in $0.3 \%$ coriander seed supplemented groups. The differences of the other group were not statistically important. There was no difference in the total number of white blood cells, in the count of heterophilis and lymphocytes, nor their ratio among the treatment groups. There was no significant difference for gamma pyruvic transferees and glutamic oxalocetic transferees enzyme activity between the treatments. The coriander seed supplementation also led to the decrease of glucose and cholesterol concentration in blood serum. Based on the results of this study, it could be advised to supplement broiler feed with $0.3 \%$ coriander seed (Saeid and Al-Nasry, 2010).

In the study conducted to determine the potential effect of coriander as growth promoting substance in one-day-old broiler 
chicks raised under summer conditions $\left(32-36{ }^{\circ} \mathrm{C}\right)$ during 42 days. The birds were fed with experimental diets with 1.0, 2.0 and $3.0 \%$ of added coriander seed. According to the obtained results, it can be concluded that the inclusion of $2.0 \%$ coriander seed in the diet improves the final weight and weekly gain. Furthermore, food consumption and feed conversion were significantly higher in the $2.0 \%$ coriander seed when compared with other treatments. In the elevated ambient temperature, especially during last two weeks of the experiment, birds that were feed diet containing $2.0 \%$ coriander seed had improved their feed intake and weight gain. According to these results, authors concluded that the inclusion of $2.0 \%$ coriander seed could be used as a natural growth promoter and reduce heat stress via improving birds' immunity. Due to its appetizing effects, digestive enzyme function improved and nutrients absorption was more efficient, while antimicrobial activity boosted the immunity and consequently improved birds' performance (Hamodi et al., 2010).

A study was conducted in order to determine the potential of coriander seed as a natural growth promoting substance in quail nutrition. Three-day-old Japanese quails were fed with diets containing coriander seed of $0.5,1.0,2.0$ and $4.0 \%$ inclusion levels. After a period of 42 days, the highest feed intake was observed in the $4.0 \%$ coriander group. The birds which had the diet containing $2.0 \%$ coriander seed showed the highest weight gain. The feed conversion ratio over the experimental period was significantly better in the group receiving $2.0 \%$ coriander seed than in the other treatments. The highest carcass yield and liver weight were also recorded in the $2.0 \%$ coriander group, while the lowest abdominal fat percenttages were present in the 1.0, 2.0 and $4.0 \%$ coriander groups. These results suggested that coriander seeds could be considered a potential natural growth promoter for poultry, and showed the best responses at a $2.0 \%$ level of inclusion (Guler et al., 2005). Apart from this, it was concluded that dietary supplementation with coriander seed would improve the quality of lipid carcass of quail by lowering saturated fatty acids proportions and by enhancing contents of polyunsaturated fatty acids, particularly of n-3 family (Ertas et al., 2005).

The effects of using different levels of coriander oil on carcass traits, blood biochemical profile and immunity parameters of broilers were investigated. This study started with one-day-old broiler chicks. Experimental groups included control and supplementation with coriander oil in concentration of $0.75,1.0,1.5$ and $2.0 \%$. The results showed that the use of different levels of coriander oil had significant effects on food intake, weight improvement, average weight and feed conversion of broilers. The highest percent of breast and thigh were observed in the group supplemented with $2.0 \%$ of coriander oil. Coriander could stimulate the digestive system in poultry, improve the function of liver and increase the pancreatic digestive enzymes. Furthermore, the presence of antioxidants and phenolic substance in coriander oil may be the main cause of improvement in breast percent of broilers carcass. The serum total cholesterol, triglycerides and low density lipoprotein concentration were significantly reduced in $1.5 \%$ coriander oil supplementation (Jang, 2011).

\section{Fennel (Foeniculum vulgare Mill.)}

Fennel seed usually contains between 2$6 \%$ of essential oil with trans-anethole as the main compound (Acimovic et al., $2015 b)$. In a study of the response of growing Japanese quail to meals enriched with different levels of fennel seeds $(0.25$, 0.50 and $0.75 \mathrm{~g} / \mathrm{kg}$ ), it was concluded that live body weight gain of quail chicks significantly increased. Feed diet containing $0.50 \mathrm{~g} / \mathrm{kg}$ fennel seed recorded the best values of feed conversion ratio, net return as well as the highest value of economic efficacy among the experimental treatments (Mahmud, 2014).

The addition of fennel seed to the basal diet $(0.5 \%)$ and the mixture of fenugreek and fennel $(0.25 \%+0.25 \%)$ can improve performance and health conditions in broiler chicks. Treatments containing medical plants showed better performance and lower total number of bacteria compared with the control. The weight and 
length of small intestine and carcass yield in birds fed with medicinal plants were higher than in the control (Saki et al., 2014).

Significant improvement in final body weight and feed efficiency were recorder when broiler chickens were feed with a fennel-added diet. In addition, chicks feed with fennel had a significantly higher number of red blood cells, hemoglobin and packet cell volume (Mohammed and Abbas, 2009).

The antioxidative effect of fennel seed when used as a feed additive in comparison with the basal diet with conventional feed additives (antibiotic and probiotic) on the quality of chicken meat was studied. Birds which consumed fennel had the lowest oxidative products in their meat, while birds on an antibiotic had the highest. The results demonstrated that the basal diet and feed additives could change the oxidative stability of chicken meat, and fennel as a feed additive could improve the oxidative quality of chicken meat (Gharaghani et al., 2013).

\section{CONCLUSIONS}

Based on the available data it can be concluded that plants from Apiaceae family can be used as supplements in broiler chicken and Japanese quail nutrition. According to reports, caraway influences the productive performance and some blood parameters, while anise has antibiotic and coccidial effects, therefore they can be used as natural alternatives for synthetic antibiotics. Coriander stimulates the digestive system, as well lowers cholesterol and alters the fatty acid profile, so it can be used as a natural growth promoter in poultry production. Fennel improves performance and health conditions in broiler chicks, final body weight and the oxidative quality of meat. In general, plants from Apiaceae family have positive effects on many different functions in the poultry organism, but their use is still limited and requires further investigation.

\section{ACKNOWLEDGEMENTS}

This paper is a part of the projects 114451-2373/2014-03 funded by Provincial Secretariat for science and technological development, Autonomus Province of Vojvodina and III 46012 funded by Ministry of Education, Science and Technological development of the Republic of Serbia.

\section{REFERENCES}

1. Acimovic, M., Oljaca, S., Jacimovic, G., Drazic, S., Tasic, S. (2011). Benefits of environmental conditions for growing coriander in Banat Region, Serbia. Natural Product Communications, 6, 1465-1468.

2. Acimovic, M., Dojcinovic, N. (2014). A review of pharmacological properties of anise (Pimpinella anisum L.). Matieres Medicales, 34, 3-17.

3. Acimovic, M., Korac, J., Jacimovic, G., Oljaca, S., Djukanovic, L., Vuga-Janjatov, V. (2014b): Influence of ecological conditions on seeds traits and essential oil contents in anise (Pimpinella anisum L.). Notulae Botanicae Horti Agrobotanici Cluj-Napoca, 42, 232-238.

4. Acimovic, M., Oljaca, S., Tesevic, V., Todosijevic, M., Djisalov, J. (2014a). Evaluation of caraway essential oil from different production areas of Serbia. Horticultural Science (Prague), 41, 122-130.

5. Acimovic, M., Kostadinovic, Lj., Popovic, S., Dojcinovic, N. (2015a). Apiaceae seeds as functional food. Journal of Agricultural Science (Belgrade), 60, 237-246.

6. Acimovic, M., Tesevic, V., Todosijevic, M., Djisalov, J., Oljaca, S. (2015b). Compositional characteristics of the essential oil of Pimpinella anisum and Foeniculum vulgare grown in Serbia. Botanica Serbica, 39, 9-14.

7. Acimovic, M., Tesevic, V., Todosijevic, M., Oljača, S., Dolijanović, Ž. (2015c). Essential oil content and composition of aniseed. Matica Srpska Journal of Natural Science, 128, 67-75.

8. Akbarian, A., Golian, A., Kermanshahi, H., De Smet, S., Michiels, J. (2015). Antioxidant enzyme activities, plasma hormone levels and serum metabolites of finishing broiler chickens reared under high ambient temperature and fed lemon and orange peel extracts and Curcuma xanthorrhiza essential oil. Journal of Animal Physiology and Animal Nutrition, 99, 150-162.

9. Brenes, A., Roura, E. (2010). Essential oils in poultry nutrition: Main effects and modes of action. Animal Feed Science and Technology, 158, 1-14.

10. Ciftci, M., Guler, T., Dalkilic, B., Ertas, N. (2005). The effect of anise oil (Pimpinella anisum L.) on broiler performance. International Journal of Poultry Science, 4, 851-855.

11. Deepak, S. (2013). Importance of Cuminum cyminum L. and Carum carvi L. in traditional medicaments - a review. Indian Journal of Traditional Knowledge, 12, 300-307.

12. Dragan, L., Titilincu, A., Dan, I., Dunca, I., Dragan, M., Mircean, V. (2010). Effects of Artemisia annua and Pimpinella anisum on Eimeria tenella (Phylum Apicomplexa) low infection in chickens. Scientia Parasitologica, 11, 77-82. 
13. El-Soud, A., El-Lithy, N., El-Saeed, G., Wahby, M., Khalil, M., Morsy, F., Shaffie, N. (2014). Renoprotective effects of caraway (Carum carvi L.) essential oil in streptozotocin induced diabetic rats. Journal of Applied Pharmaceutical Science, 4, 27-33.

14. Ertas, N., Guler, T., Ciftci, M., Dalkilic B., Yilmaz, O. (2005). The effect of a dietary supplement coriander seeds on the fatty acid composition of breast muscle in Japanese quail. Revue De Medecine Veterinaire (Toulouse), 156, 514-518.

15. Gharaghani, H., Shariatmadari, F., Torshizi, K. (2013). Comparison of oxidative quality of meat of chickens feed corn or wheat based diets with fennel (Foeniculum vulgare Mill.), antibiotic and probiotic as feed additive, under different storage conditions. Archiv Fur Geflugelkunde, 77, 199-205.

16. Giannenas, I., Bonos, E., Christaki, E., FlorouPaneri, P. (2013). Essential oils and their applications in animal nutrition. Medicinal and Aromatic Plants, 2, 6, 1-12.

17. Grashorn, M. (2010). Use of phytobiotics in broiler nutrition - an alternative to in feed antibiotics? Journal of Animal and Feed Sciences, 19, 338-347.

18. Guler, T., Ertas, N., Ciftci, M., Dalkilic, B. (2005). The effect of coriander seed (Coriandrum sativum L.) as diet ingredient on the performance of Japanese quail. South African Journal of Animal Science, 35, 260-266.

19. Hamodi, J., A-Mashhadani, H., Al-Jaff, K., AlMashhadani, E. (2010). Effect of coriander seed (Coriandrum sativum L.) as diet ingredient on broilers performance under high ambient temperature. International Journal of Poultry Science, 9, 968-971.

20. Hassan, E., Abdel-Raheem, S. (2013). Response of growing buffalo calves to dietary supplementation of caraway and garlic as natural additives. World Applied Sciences Journal, 22, 408-414.

21. Huyghebaert, G., Ducatelle, R., Van Immerseel, F. (2011). An update on alternatives to antimicrobial growth promoters for broilers. Veterinary Journal, 187, 182-188.

22. Jafari, B. (2011). Influence of caraway on improved performance and blood parameters of Japanese quails. Annals of Biological Research, 2, 474-478.

23. Jang, P. (2011). Effect of different levels of coriander oil on performance and blood parameters of broiler chickens. Annals of Biological Research, 2, 578-583.

24. Khajeali, Y., Kheiri, F., Rahimian, Y., Faghani, M., Namjo, A. (2012). Effect of use different levels of caraway (Carum carvi L.) powder on performance, some blood parameters and intestinal morphology on broiler chicks. World Applied Sciences Journal, 24, 1044-1048.

25. Kostadinovic Lj., Levic, J., Popovic, S., Cabarkapa, I., Puvaca, N., Djuragic, O., Kormanjos, S., 2015b. Dietary inclusion of Artemisia absinthium for management of growth performance, antioxidative status and quality of poultry meat. European Poultry Science, 79, 1-10.

26. Kostadinovic, Lj., Puvaca, N., Popovic, S., Levic, J. (2015a). Medicinal plants in poultry nutrition as an anticoccidial drugs alternatives. World Poultry Science Journal, 71, 27-36.

27. Lee, K., Everts, H., Beynen, A. (2004). Essential oils in broiler nutrition. International Journal of Poultry Science, 3, 738-752.

28. Mahmud, H. (2014). Response of growing Japanese quail to different levels of fennel seeds meal. Egyptian Poultry Science, 34, 795-807.

29. Mohammed, A., Abbas, R. (2009). The effect of using fennel seeds (Foeniculum vulgare L.) on productive performance of broiler chickens. International Journal of Poultry Science, 8, 642644.

30. Panda, K., Rama, R., Raju, M. (2006). Natural growth promoters have potential in poultry feeding systems. Feed Technology, 10, 23-25.

31. Puvaca, N., Kostadinovic, Lj., Ljubojevic, D., Lukac, D., Levic, J., Popovic S., Novakov, N., Vidovic, B., Djuragic, O. (2015). Effect of garlic, black pepper and hot red pepper on productive performances and blood lipid profile of broiler chickens. European Poultry Science, 79, 1-13.

32. Puvaca, N., Stanacev, V., Glamocic, D., Levic, J., Peric, L., Stanacev, V., Milic, D. (2013). Beneficial effects of phytoadditives in broiler nutrition. World Poultry Science Journal, 69, 2734.

33. Rattan, S., Satpathy, G., Gupta, R. (2014). Formulation of biscuits with Glycyrrhiza glabra root extract, Ocimum sanctum and Pimpinella anisum extract added as a nutraceutical. Journal of Pharmacognosy and Phytochemistry, 3, 1016.

34. Saeid, M., Al-Nasry, S. (2010). Effect of dietary coriander seeds supplementation on growth performance carcass traits and some blood parameters of broiler chickens. International Journal of Poultry Science, 9, 867-870.

35. Saki, A., Kalantar, M., Rahmatnejad, E., Mirzaaghatabar, F. (2014). Health characteristics and performance of broiler chicks in response to Trigonella foenum graecum and Foeniculum vulgare. Iranian Journal of Applied Animal Science, 4, 387-391.

36. Soltan, M., Shewita, R., El-Katcha, M. (2008). Effect of dietary anise seeds supplementation on growth performance, immune response, carcass traits and some blood parameters of broiler chickens. International Journal of Poultry Science, 7, 1078-1088.

37. Titilincu, A., Santha, B., Cozma, V. (2008). Effects of Polioel 3 on sporulation and infectivity of Eimeria oocysts. Lucrari Stiinlifice Medicina Veterinara, 41, 372-378.

38. Windisch, W., Rohrer, E., Schedle, K. (2009). Phytogenic feed additives to young piglets and poultry: mechanisms and application. In Phytoin Animal Nutrition. Ed. T. Steiner, Nottingham University Press, pp. 19-39.

39. Yazdi, F., Ghalamkari, G., Toghiani, M., Modaresi, M., Landy, N. (2014). Anise seed (Pim- 
pinella anisum L.) as an alternative to antibiotic growth promoters on performance, carcass traits and immune responses in broiler chicks. Asian Pacific Journal of Tropical Disease, 4, 447-451.

40. Yazdi, F., Ghalamkari, G., Toghiani, M., Moda- resi, M., Landy, N. (2011). Effect of adding different levels seed cake of Pimpinella anisum to antibiotics-free diets of broilers on growth performance and characteristics of lymphoid organ. International Proceedings of Chemical, Biological and Environmental Engineering, 3, 75-77.

\title{
ФИТОХЕМИЈСКИ САСТАВ ОДАБРАНИХ БИЉАКА ИЗ ФАМИЛИЈЕ APІАСЕАЕ И ЊИХОВ БИОЛОШКИ ЕФЕКАТ У ИСХРАНИ ЖИВИНЕ
}

\author{
Аћимовић Г. Милица ${ }^{* 1}$, Костадиновић М. љиљана ${ }^{1}$, Пувача М. Никола ${ }^{2}$, \\ Поповић Ј. Сања ${ }^{1}$, Урошевић И. Мирослав ${ }^{3}$ \\ 'Универзитет у Новом Саду, Научни институт за прехрамбене технологије у Новом Саду, \\ 21000 Нови Сад, Булевар цара Лазара бр. 1, Србија \\ ${ }^{2}$ Универзитет у Новом Саду, Пољопривредни фракултет, 21000 Нови Сад, Трг Доситеја \\ Обрадовића бр. 8, Србија \\ ${ }^{3}$ Научни институт за репродукцију и вештачко осемењивање домаћих животиња \\ „Темерин“, 21235 Темерин, Инд. зона бб., Србија
}

Сажетак: Зрели плодови биљака из фамилије Аріасеае користе се у народној медицини за лечење дигестивних поремећаја. Такође, могу да се користе и у ветерини и исхрани животиња, посебно живине, као имуностимуланти и као природни антибиотици. Биљке из фрамилије Аріасеае побољшавају перформансе живине, а делују и превентивно на појаву болести. У овом раду дат је преглед литературних података о употреби кима, аниса, коријандра и коморача у исхрани бројлерских пилића и јапанске препелице као и њихов ефекат на продуктивне перформансе, параметре крви, холестерол и маснокиселински профил.

Кључне речи: ким, анис, коријандар, коморач, продуктивне перфоормансе, природни антибиотици

Received: 9 December 2015

Accepted: 8 February 2016 